\title{
Recent changes in rainfall characteristics and their influence on thresholds for debris flow triggering in the Dolomitic area of Cortina d'Ampezzo, north-eastern Italian Alps
}

\author{
M. Floris ${ }^{1}$, A. D'Alpaos ${ }^{1}$, C. Squarzoni ${ }^{1}$, R. Genevois ${ }^{1}$, and M. Marani ${ }^{2}$ \\ ${ }^{1}$ Department of Geosciences, University of Padova, Padova, Italy \\ ${ }^{2}$ Department IMAGE, University of Padova, Padova, Italy
}

Received: 9 November 2009 - Revised: 28 January 2010 - Accepted: 1 February 2010 - Published: 26 March 2010

\begin{abstract}
In this paper, we examine variations in climate characteristics near the area of Cortina d'Ampezzo (Dolomites, Eastern Italian Alps), with particular reference to the possible implications for debris-flow occurrence. The study area is prone to debris-flow release in response to summer high-intensity short-duration rainfalls and, therefore, it is of the utmost importance to investigate the potential increase in debris-flow triggering rainfall events. The critical rainfall threshold is agreed to be a crucial triggering factor for debris-flows. Data from a monitoring system, placed in a catchment near Cortina (Acquabona), show that debris-flows were triggered by rainfalls with peak rainfall intensities ranging from 4.9 to $17.4 \mathrm{~mm} / 10 \mathrm{~min}$.

The analyses of meteorological data, collected from 1921 to 1994 at several stations in the study area, show a negative trend of annual rainfall, a considerable variation in the monthly rainfall distribution, and an increase in the temperature range, possibly related to global climate changes. Moreover, high-intensity and short-duration rainfall events, derived from data collected from 1990 and 2008, show an increase in exceptional rainfall events. The results obtained in a peak-over-threshold framework, applied to the rainfall data measured at the Faloria rain gauge station from 1990 to 2008 , clearly show that the interarrival time of over-threshold events computed for different threshold values decreased in the last decade. This suggests that local climatic changes might produce an increase in the frequency of rainfall events, potentially triggering debris flows in the study area.
\end{abstract}

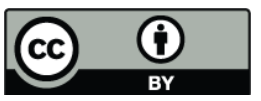

Correspondence to: $\mathrm{M}$. Floris (mario.floris@unipd.it)

\section{Introduction}

In the last decade, several authors have suggested that climate changes are leading to a rapid increase in the frequency and intensity of extreme rainfall events (e.g., Gong and Wang, 2000; Easterling et al., 2000; Monirul Qader Mirza, 2002; Fauchereau et al., 2003; Fowler and Kilsby, 2003; Fowler et al., 2005; Sillmann and Roeckner, 2008). As a consequence, the frequency of rainfall-related phenomena, such as floods, landslides and debris flows, is changing all over the world (Eybergen and Imeson, 1989; Haeberli et al., 1990; Rickenmann and Zimmermann, 1993; Evans and Clague, 1994; Blijenberg, 1998; Van Steijn, 1996, 1999; Gärtner et al., 2003; Jomelli et al., 2007, 2009; Pelfini and Santilli, 2008), with potentially huge economic and social implications. However, the influence of global climate change on the increase in intense rainfall events in the Mediterranean area is still not completely understood (Bodini and Cossu, 2010). In fact, results from previous studies show contrasting trends of heavy rainfall events in the past century between western and eastern Europe (Alpert et al., 2002) and insular and peninsular Italy (Brunetti et al., 2001).

Debris flows are highly hazardous hydrological processes common in the Alpine environment, and the progressive increase in the socio-economic activity in these areas has led to an increase in the associated potential risk. In the Upper Boite Valley (Dolomites, Eastern Italian Alps, Fig. 1), the significant increase in debris flow frequency in recent years (Armento, 2007) and the strong effect of rainfall on the generation of debris flows has prompted a re-definition of rainfall thresholds. Rainfall-triggering thresholds are very important in landslide and debris-flow hazard evaluation because they form the basis of real-time instability early warning

Published by Copernicus Publications on behalf of the European Geosciences Union. 


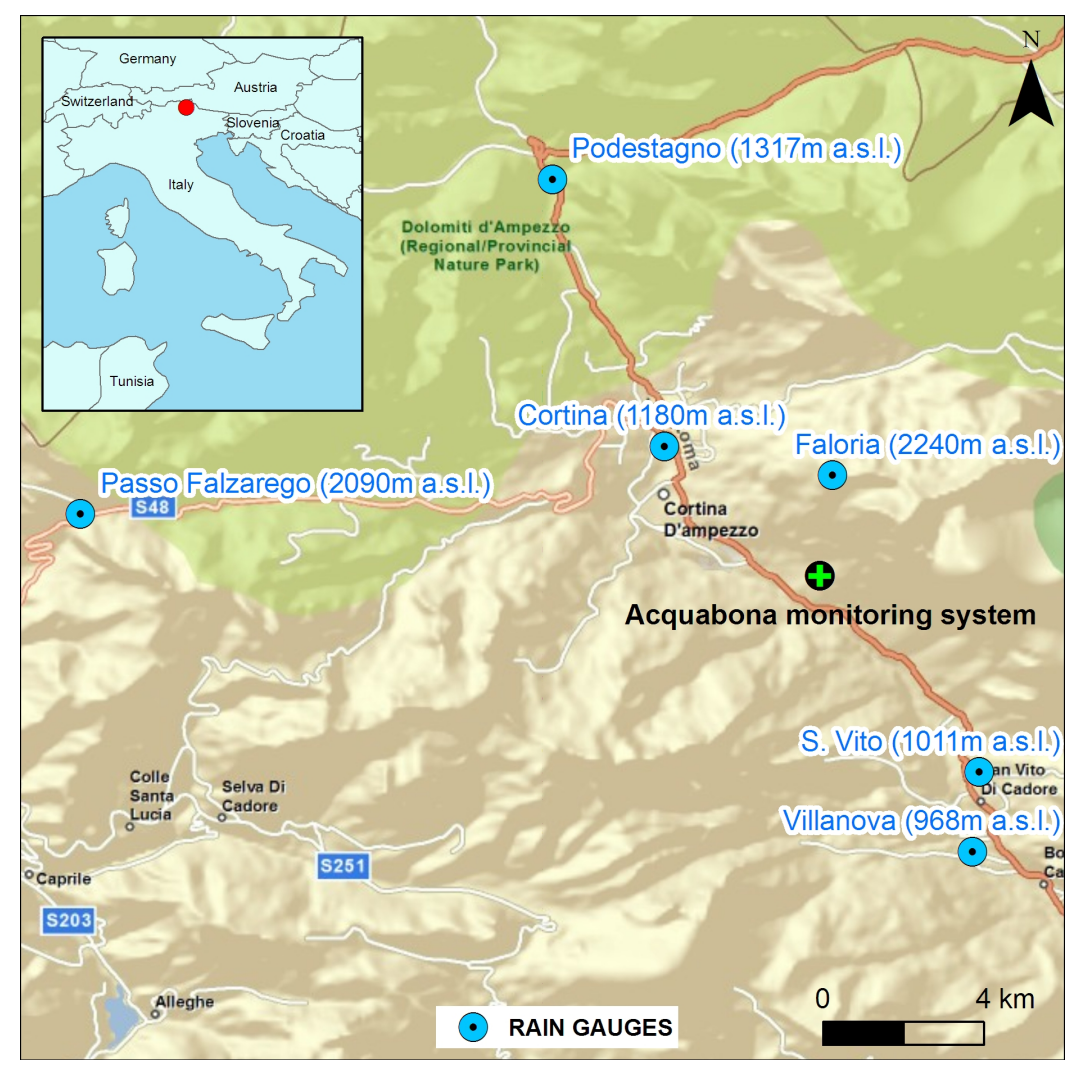

Fig. 1. Location of the study area, with the positions of rainfall gauges considered in the study and of the Acquabona monitoring system.

systems (Keefer et al., 1987; Tecca et al., 2003; Chen et al., 2006). As observed by Shieh et al. (2009), a number of researchers have analysed precipitation data to determine rainfall thresholds for debris flow triggering. To establish such rainfall thresholds, both rainfall intensity and duration have been considered as possible indicators (e.g., Caine, 1980; Wieczorek, 1987; Keefer et al., 1987; Wilson and Wieczorek, 1995; Chen et al., 2005; Galgaro et al., 2005). Takahashi (1981a) and Shieh et al. (1995) considered rainfall intensity and cumulative precipitation as possible indicators to define critical rainfall thresholds for warning systems in Japan and Taiwan, respectively. Shieh (2002) applied cluster analysis to establish the rainfall threshold for all hazardous streams in Taiwan, which yielded a better disaster warning and prevention system. Not surprisingly, the published thresholds are distinctly different, as they are based on different datasets from areas with varying geological and climatic settings and, therefore, triggering thresholds should be developed for each region separately (Terlien, 1998). Debris flows can be initiated from different processes, like slides or surface-water runoff (Coe et al., 2008a). In the study area, channelised debris flows characterised by bed material mobilisation mainly occur, for which three essential factors are required: i) available sediment material, ii) steep stream slopes, and iii) surface-water runoff, mainly deriving from rainfall (Takahashi, 1981b). The water inflows required for debris-flow occurrence are very sensitive to variations in the rainfall regime, which may be associated with climatic changes.

This paper aims at examining variations in climate characteristics in the study area, with reference to the possible implications for debris-flow occurrence on a local scale. In the study area, rainfall intensity and debris-flow discharge are monitored in the experimental basin of Acquabona (Cortina d'Ampezzo, Italy), as described in detail by Galgaro et al. (2005). In the Cortina area, Genevois et al. (2003) mapped 325 debris-flow prone watersheds. Because of the homogeneity in the geological and geomorphological settings, the mechanisms of initiation and propagation of the debris flows can be considered to be quite similar. Nevertheless, the rainfall triggering events do not homogeneously affect the entire area because of the topographic and morphometric settings, such as slope aspect and the position in relation to the storm cell paths. For this reason, the available historical data collected at all of the rain gauges within the area were considered. The objective of this study is to investigate the relationship between the variation in the frequency of rainfall events that may trigger debris flows and the changes in regional climatic and meteorological conditions. Such an analysis aims at determining whether the conditions favourable for triggering of debris flows are currently increasing or decreasing in the study area. 
The paper is organised as follows: Sect. 2 briefly describes the geomorphological features of the Upper Boite Valley (Dolomites, Eastern Italian Alps). Section 3 reports the typical climatic conditions of the study area and their changes in time, with reference to the annual maximum and minimum temperatures and to the total annual and monthly rainfall, obtained using data from a network of meteorological stations. Section 4 discusses the triggering rainfall thresholds for debris-flow occurrence, which have been identified from empirical relationships between rainfall data and debris-flow events collected by the Acquabona monitoring system. In Sect. 5, we carry out some analyses on the exceedance of the considered triggering rainfall threshold during the period 1990-2008, and apply a peak-overthreshold framework to the available rainfall dataset. Finally, Sect. 6 contains some discussion and our conclusions.

\section{The study area}

The study area is located in the N-S-trending Upper Boite River Valley (Eastern Dolomites, Italy) (Fig. 1). The relief at the highest elevations (from 2500 to $3200 \mathrm{~m}$ a.s.1.) is characterised by steep rock cliffs of Upper Triassic to Lower Jurassic dolomite and limestone, whereas Lower-Middle Triassic pelite form the gentler lower slopes (Panizza et al., 1996; APAT, 2007). A thick talus covers the slopes from the base of the rock cliffs $\left(35-40^{\circ}\right)$ to the valley bottom $\left(5-15^{\circ}\right)$; this consists of poorly sorted debris containing boulders up to $3-4 \mathrm{~m}$ in diameter and includes heterogeneous scree, alluvium and old debris flow deposits.

Debris flows occur as hillside flows or in channels, draining very steep rocky small catchments with no vegetation and almost no soil cover; channels are generally deeply incised in the thick talus slopes. The watersheds respond dramatically to high-intensity, short-duration, localised summer rainfalls, with intensities higher than $15 \mathrm{~mm}$ in $30 \mathrm{~min}$, rapidly generating high runoff discharge, generally above $1 \mathrm{~m}^{3} / \mathrm{s}$ (Genevois et al., 2000). Debris flows generally start as a channel-bed failure caused by surface water flow (Takahashi, 1978, 1991, 2000; Griffiths et al., 1997; Coe et al., 2003; Cannon et al., 2003). This condition is quite common in the European Alps (Tognacca and Bezzola, 1997; Berti et al., 1999; Tognacca et al., 2000; Tecca and Genevois, 2009). Debris-flow occurrence in the study area is unaffected by the long-term antecedent precipitation due to the high permeability of soils.

Genevois et al. (2003) mapped 325 debris flow-prone watersheds with similar characteristics (Table 1) in the geomorphological hazard map of this area. The debris flows occur with a yearly or shorter frequency, and their volume estimates range from 6000 to $30000 \mathrm{~m}^{3}$. We note that most of the mapped basins are characterised by supplyrich conditions, i.e., the basins are continuously fed with debris which can be involved in debris-flow phenomena.
Table 1. Morphometric characteristics of the debris flow near Cortina d'Ampezzo. (Data from "World Wide Web Debris-Flow Geodatabase", http://www.geoscienze.unipd.it/www-dfg/).

$\begin{array}{ll}\text { mean catchment area } & 0.061 \mathrm{~km}^{2} \\ \text { mean maximum elevation of the catchments } & 2387 \mathrm{~m} \text { a.s.1. } \\ \text { mean minimum elevation of the catchments } & 2016 \mathrm{~m} \text { a.s.l. } \\ \text { mean catchment slope } & 47^{\circ} \\ \text { mean channel length } & 0.46 \mathrm{~km} \\ \text { mean channel slope } & 28^{\circ}\end{array}$

Discharges of debris often affect the buildings related to farming, small factories and tourism, and dam the Boite River.

\section{Climate}

The climatic conditions of the Cortina d'Ampezzo area are typical of an Alpine environment. The annual precipitation within the study area, occurring also as snowfall from November to May, is about $1150 \mathrm{~mm}$ distributed over about 110 days per year. Thunderstorms are common during the summer, with peak rainfall intensities ranging from 1.36 to $3.66 \mathrm{~mm} / \mathrm{min}$. This kind of event, generated by small storm cells, normally impacts a very limited area and presents high rainfall gradients in the horizontal direction as well as with elevation.

To investigate, in detail, the main climatic features of the Cortina d'Ampezzo area, we considered the historical daily rainfall and annual temperature data, collected at four meteorological stations of the regional hydrological service, namely Podestagno, Cortina, Passo Falzarego and San Vito, located in the study area (Fig. 1). The available rainfall data cover 1920 to 2008, while the temperature data have been recorded since 1938 .

Figure 2 shows the annual mean maximum and minimum temperatures at the Cortina station between 1938 and 1994. An increase in the annual mean maximum temperature of $3{ }^{\circ} \mathrm{C}$ was observed, whereas the annual mean minimum temperature decreased slightly (by about $1^{\circ} \mathrm{C}$ ). Around the same period, changes in the amount of total annual rainfall and in the distribution of monthly rainfall can also be observed (Fig. 3). At Podestagno, Cortina and San Vito stations (Fig. 3a, b, and d), a negative trend in the total annual rainfall is displayed. The trend observed at Passo Falzarego (Fig. 3c) does not seem to be representative, due to a lack of data in the period 1920-1936. The distribution of monthly rainfall shows a remarkable variation in the period 1920-2008 at each of the four stations (Fig. 3e-h). Since about 1950, an increase in the mean monthly rainfall occurred during the autumn (October and November), while rainfall conditions in the summer (from June to August) remained constant. For Podestagno, Cortina and San Vito stations (Fig. 3e, f, and h), 
Table 2. Main characteristics of debris flows and related rainfall data recorded at Acquabona from 1997 to 2001 (modified from Tecca and Genevois, 2009). The minimum debris-flow triggering threshold is highlighted in bold.

\begin{tabular}{|c|c|c|c|c|c|c|c|c|}
\hline \multirow[t]{2}{*}{ Date } & \multirow[t]{2}{*}{ Hour } & \multirow{2}{*}{$\begin{array}{l}\text { Total volume } \\
\qquad\left(\mathrm{m}^{3}\right)\end{array}$} & \multicolumn{3}{|c|}{ Rainfall } & \multirow{2}{*}{$\begin{array}{c}\text { Mean front } \\
\text { velocity range } \\
(\mathrm{m} / \mathrm{s})\end{array}$} & \multirow{2}{*}{$\begin{array}{l}\text { Peak water } \\
\text { discharge } \\
\left(\mathrm{m}^{3} / \mathrm{s}\right)\end{array}$} & \multirow{2}{*}{$\begin{array}{c}\text { Total water inflow } \\
\text { at initiation area } \\
\qquad\left(\mathrm{m}^{3}\right)\end{array}$} \\
\hline & & & $\begin{array}{l}\text { 10-min intensity } \\
(\mathrm{mm})\end{array}$ & $\begin{array}{l}\text { Total } \\
(\mathrm{mm})\end{array}$ & $\begin{array}{l}\text { Duration } \\
\text { (min) }\end{array}$ & & & \\
\hline 12 Jun 1997 & 1530 & 6000 & 10 & 23.8 & 55 & $3.1-9.0(\mathrm{a})$ & 4.02 & 7140 \\
\hline 25 Jul 1998 & 2010 & $600-700$ & 4.9(a) & 8.1 & 35 & $0.47-0.83$ & 1.97 & 2430 \\
\hline 27 Jul 1998 & 2020 & $400-500$ & 5.8 & 12.5 & 40 & $0.77-1.17$ & 2.33 & 3750 \\
\hline 17 Aug 1998 & 2015 & 8000-9000 & 14.7 & 22.35 & 55 & $1.82-7.69$ & 5.91 & 8760 \\
\hline 28 Jul 1999 & 1530 & $6000-7000$ & 17.4 & 46.2 & 105 & & 6.99 & 14220 \\
\hline 30 Sep 2000 & 1810 & 10000 & 9.2 & 16.4 & 50 & & 3.49 & 4935 \\
\hline 30 Jun 2001 & 2130 & 30000 & 8.6 & 16.6 & 55 & $2.0-7.2(\mathrm{a})$ & 3.45 & 5000 \\
\hline
\end{tabular}

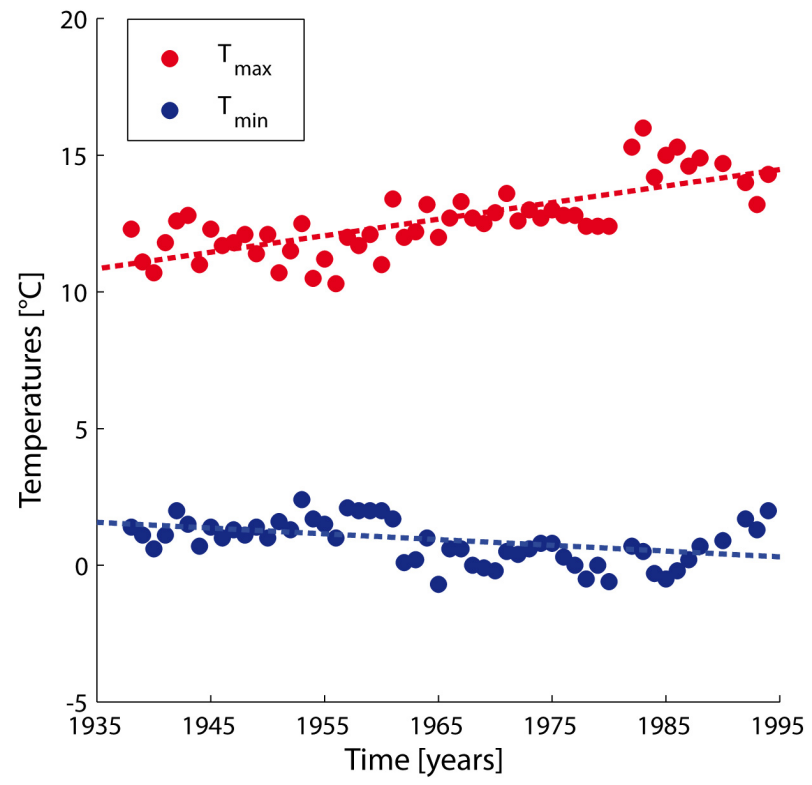

Fig. 2. Mean annual maximum (solid red circles) and minimum (solid blue circles) temperatures at the Cortina meteorological station between 1938 and 1994.

a decrease in monthly rainfall from February to May can be observed. The results of this analysis suggest that the study area may have experienced a climate change during the second half of the past century.

\section{Debris-flow discharge and triggering rainfall threshold}

Rainfall data recorded at the Acquabona (Cortina d'Ampezzo) debris-flow monitoring system (Tecca et al., 2003) were analysed to assess the minimum rainfall triggering threshold for debris flow occurrence, as the
Acquabona basin, due to its geomorphological, lithological and hydrological characteristics, can be considered as representative of the whole study area. The rain gauge is installed in the debris-flow initiation area, and sampled rainfall at $0.20 \mathrm{~s}(5 \mathrm{~Hz})$.

We considered rainfall data recorded from 1997 to 2001 . During this period, seven debris-flow events occurred (Table 2). We selected the following variables for the analysis of rainstorms and discharges in the Acquabona Basin: total rainfall, maximum rainfall intensity (over $10 \mathrm{~min}$ ), and rainfall duration.

Debris flows were generally triggered by rainfalls of high intensity and durations of less than one hour. The total amount and duration are considered from the beginning of the rainfall until the onset of the debris flow. In Acquabona, antecedent rainfall does not represent a significant factor for debris-flow occurrence because of the high permeability of the coarse debris. We, therefore, focused our analysis on single bursts, defined as continuous periods having rainfall intensities above $0.5 \mathrm{~mm} / 5 \mathrm{~min}$ and containing at least one peak exceeding a second (and higher) intensity threshold that will be discussed later. This definition is similar to the criterion adopted by Gregoretti and Dalla Fontana (2008) in their hydrological investigation on the value of the peak discharge for headwater basins; they considered continuous periods having rainfall intensities greater than $0.8 \mathrm{~mm} / 5 \mathrm{~min}$.

The initial debris surges in Acquabona are always associated with critical peak rainfall intensities measured over 10 min (Berti et al., 1999, 2000, Tecca and Genevois, 2009), as also observed in Japan (Suwa and Okuda, 1985) and in Colorado, USA (Coe et al., 2008b). The delay between the maximum rainfall intensity over $10 \mathrm{~min}$ and the debris flow initiation corresponds to the time required to saturate the loose debris that fills the channel in the initiation area. The time of occurrence of debris flows was between 35 and $105 \mathrm{~min}$ after the onset of the rainfall, generally about $30 \mathrm{~min}$ after the peak rainfall intensity over $10 \mathrm{~min}$. In this 

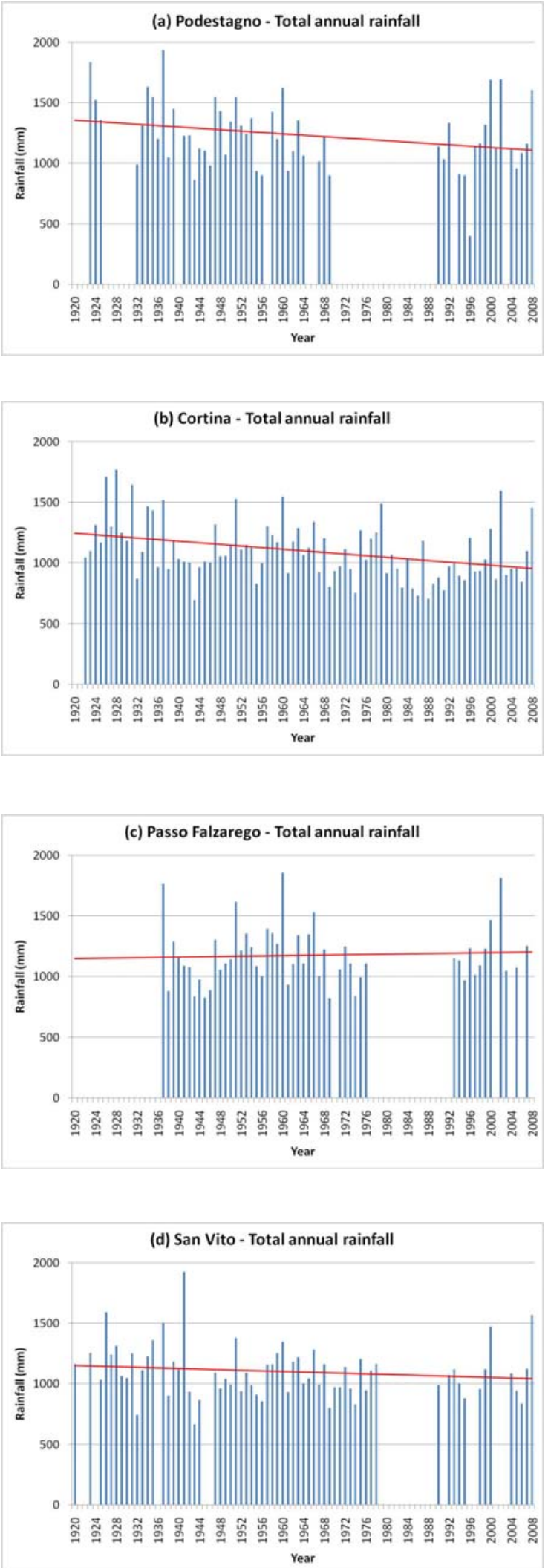
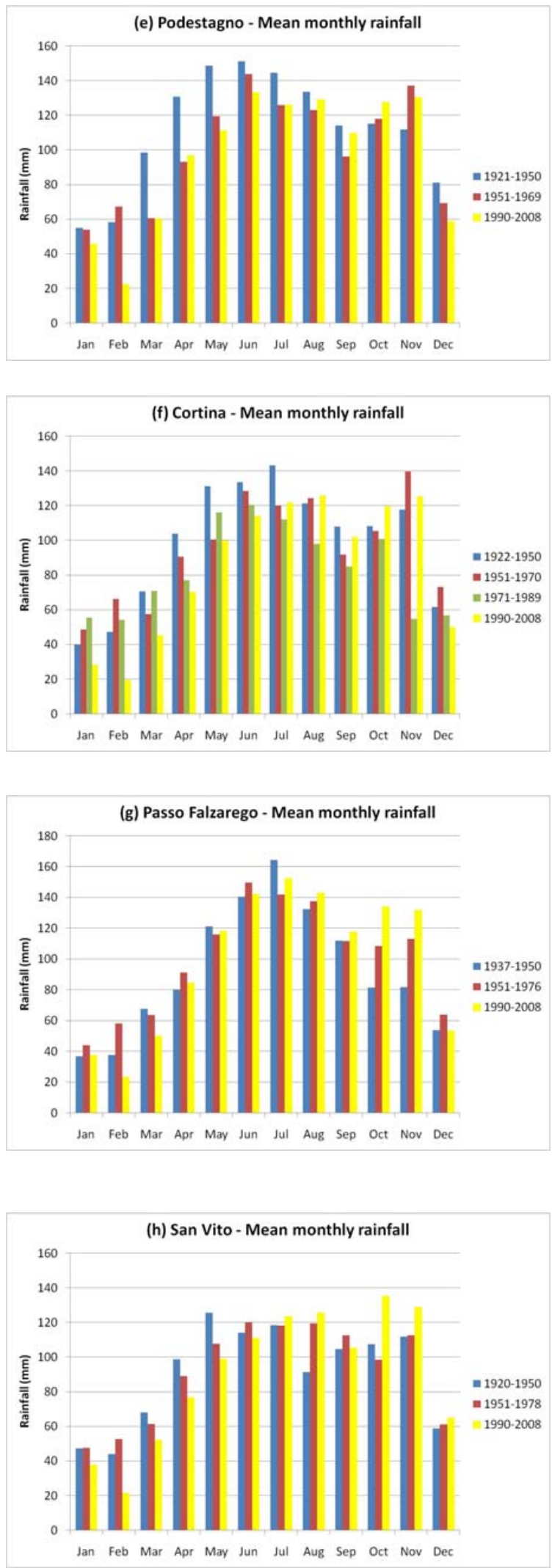

Fig. 3. Rainfall data at Podestagno, Cortina, Passo Falzarego and San Vito meteorological stations. Total annual rainfall (a-d); the red line is representative of the trend. Mean monthly rainfall for different periods $(\mathbf{e}-\mathbf{h})$. 


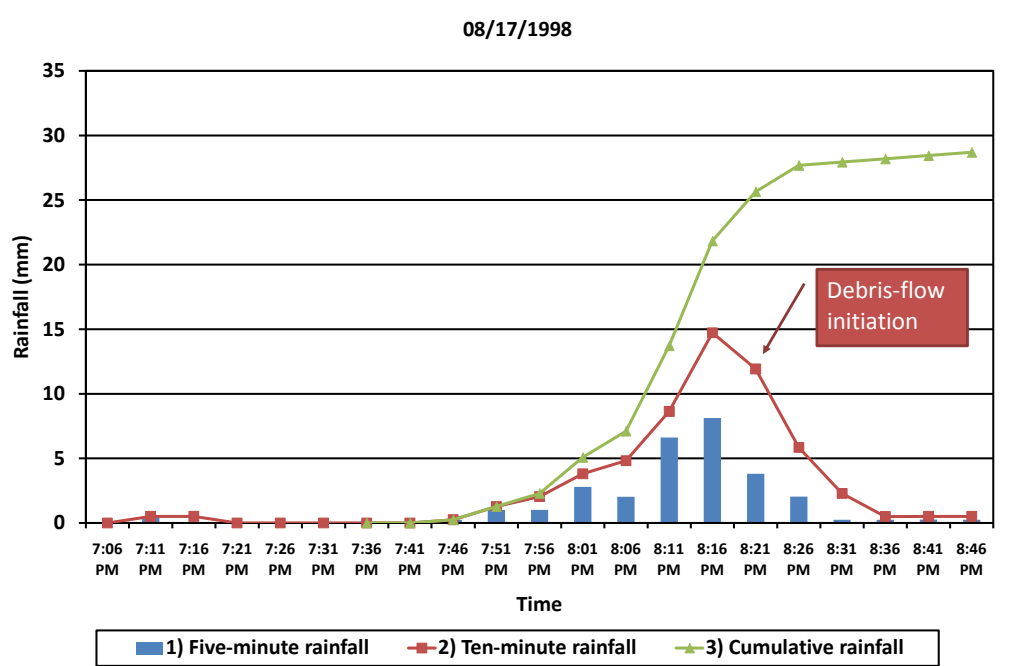

Fig. 4. The rainfall event triggering the debris flow at Acquabona on 17 August 1998 at 08:21 p.m. The plot shows that the debris flow initiated just after the maximum of ten-minute rainfall.

period, the total rainfall amount varied from about 8.1 to $46.2 \mathrm{~mm}$, and the peak rainfall intensity ranged from 4.9 to $17.4 \mathrm{~mm} / 10 \mathrm{~min}$. Figure 4 shows an example of a rainfall event triggering a debris flow.

A comparison with some past rainfall data indicates that rainfall of similar or even higher intensity and larger accumulated precipitations have been recorded without a debris-flow occurrence. Among others, a 50-min rainfall with a peak intensity of $13 \mathrm{~mm}$ per $10 \mathrm{~min}$ was recorded on 14 July 1997 , definitely greater than the precipitation triggering the debris flow of 27 July 1998 (see Table 2). Although the limited number of cases does not allow us to define a statistically validated triggering threshold for debris-flow occurrence, the data so far collected emphasize that debris flows do not occur with a rainfall intensity below $4.9 \mathrm{~mm}$ over $10 \mathrm{~min}$, which represents the minimum triggering threshold.

\section{Analysis of threshold exceedances}

From 1990, the regional meteorological network has been updated; the current rainfall dataset is composed of data collected with a temporal resolution of five minutes. Five automatic rain gauges, namely Faloria, Podestagno, Cortina, Passo Falzarego and Villanova (see Fig. 1), were considered in analysing the occurrence of rainfall events displaying characteristics similar to those of the events that triggered debris flows. According to the observations reported in the previous section, the rainfall events with maximum intensities higher than $4.9 \mathrm{~mm} / 10 \mathrm{~min}$ were considered. Moreover, due to the fact that during a single rainfall event, the fixed threshold (i.e., $4.9 \mathrm{~mm} / 10 \mathrm{~min}$ ) can be exceeded more than once, single 10-min rainfall values exceeding the minimum triggering threshold were also considered. The number of threshold exceedances was calculated between 1990 and 2008, by considering a sliding window of eight years, which allowed us to consider overlapping periods containing a statistically significant number of exceedances. For each station, the results obtained from the analysis are shown in Fig. 5, which exhibits the total number of rainfall events and of values exceeding the minimum triggering threshold of $4.9 \mathrm{~mm} / 10 \mathrm{~min}$, over each 8-year period. It clearly emerges that the considered stations display quite different trends over the considered periods, because the number of over-threshold events and the number of exceedances are characterised by important variations among the five considered stations. In the case of Faloria and Podestagno (Fig. 5a and c), there is a marked positive trend in the number of both rainfall events and exceedances of the minimum triggering threshold. This indicates that, in the last 19 years, intense rainfall events have become more frequent. At Cortina station, the number of events increases, whereas the number of exceedances seems to remain quite constant throughout the considered period, possibly showing that the intensity of the over-threshold events is not undergoing important changes (Fig. 5b). Passo Falzarego station shows a fairly constant trend (Fig. 5d). Villanova station, unlike the other examined rain gauges, shows a slight negative trend in both the number of events and total exceedances (Fig. 5e).

All of the threshold exceedances observed in the considered period (1990-2008) occurred between May and October. Most events occur during the summer period, in particular, June, July, and August, whereas critical events very rarely occur in May and October (Fig. 6). The distribution of exceedances is similar for Faloria, Cortina and Falzarego stations, with the maximum value in July, while for Podestagno station the maximum is in August. This shows, once again, the local variability of extreme rainfall event occurrence in the study area. 

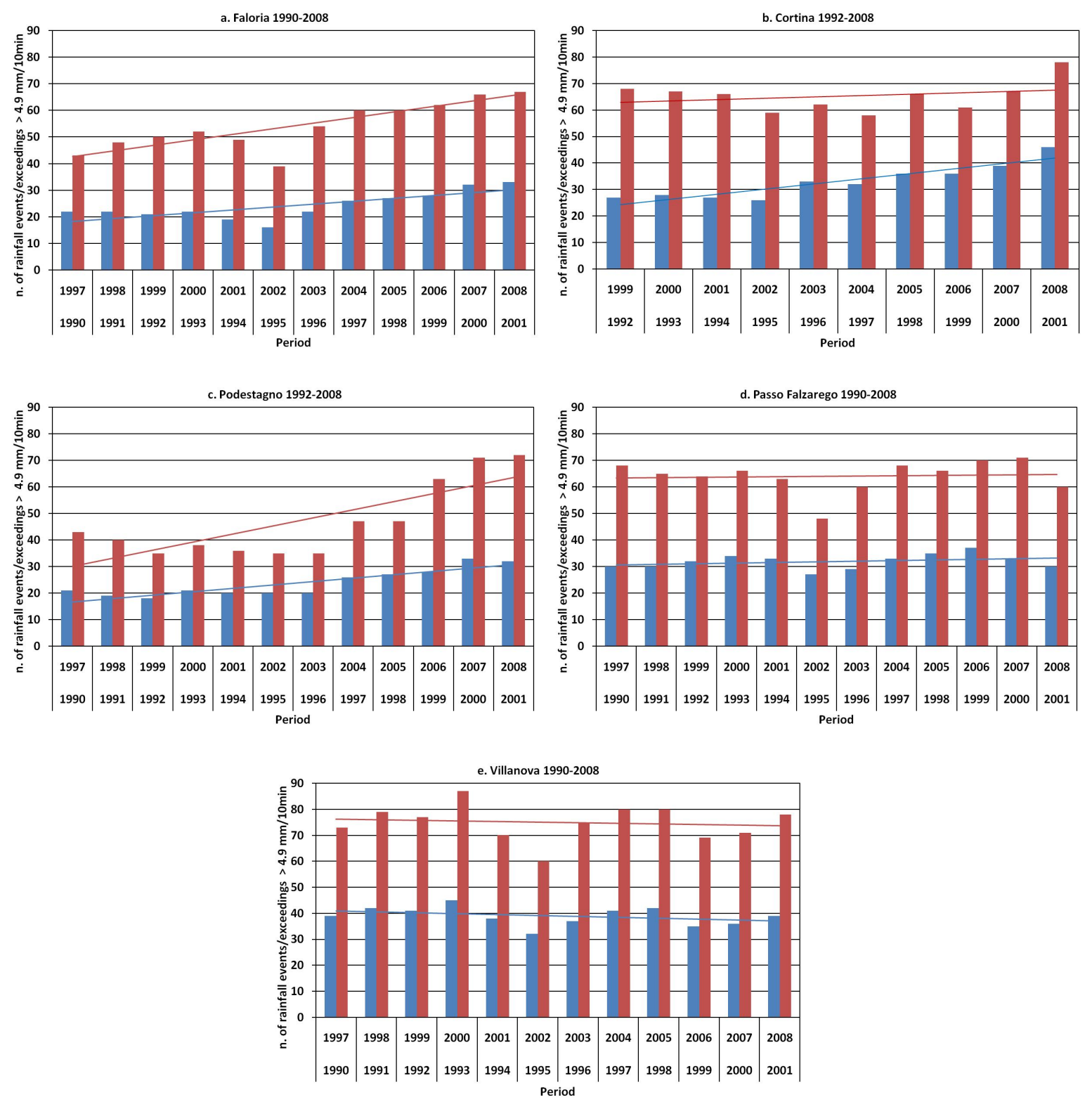

Fig. 5. Number of rainfall events (blue bars) and number of exceedances (red bars) determined on the basis of rainfall data measured at the meteorological stations Faloria (a), Cortina (b), Podestagno (c), Passo Falzarego (d), and Villanova (e) during the period 1990-2008. The blue and red lines are representative of the trend of numbers of rainfall events and exceedances, respectively.

We note that an approach based on the extreme value distributions, such as the General Extreme Value (GEV) distribution, to investigate the probability of occurrence of the considered rainfall threshold (i.e., $4.9 \mathrm{~mm} / 10 \mathrm{~min}$ ), cannot be applied, since such a threshold is on average exceeded more than three times per year in the considered period. Figure 7 shows some results of an analysis carried out in a Peak-OverThreshold (POT) framework (see, for example, the review paper by Lang, 1999), which basically allows one to consider more than one rainfall peak per year in order to increase the available information with respect to procedures that use annual maximum rainfall data. Such an approach is particu- larly effective for this case because the interarrival time of the considered threshold is shorter than one year. Furthermore, the POT framework allowed us to investigate the frequency of occurrence of over-threshold events for different threshold values, thus, extending the previously presented statistical analyses (Figs. 5 and 6).

In particular, Fig. 7a portrays the total number of exceedances over the considered period, for different values of the critical threshold, whereas Fig. 7b portrays the average annual number of over-threshold events, $\lambda$, which is basically the inverse of the interarrival time. It clearly shows that the interarrival time $(1 / \lambda)$ increases for increasing values of 


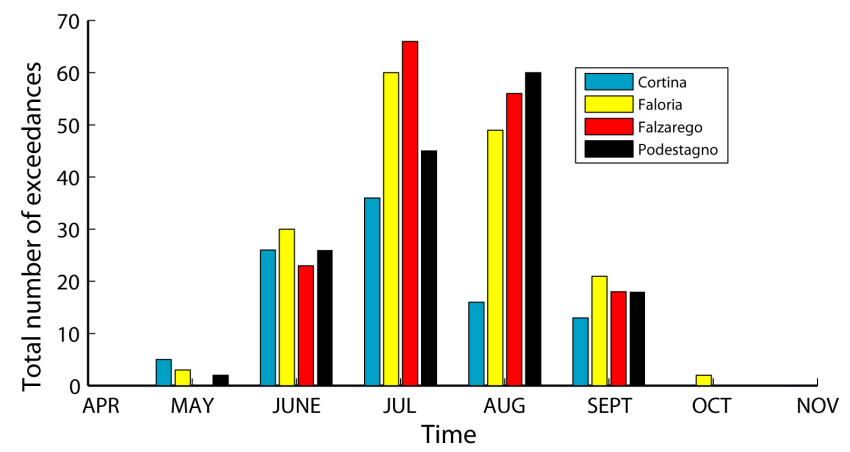

Fig. 6. Distribution of the total number of exceedances throughout the year, at Cortina, Faloria, Falzarego and Podestagno stations, determined on the basis of rainfall data measured during the period 1990-2008.
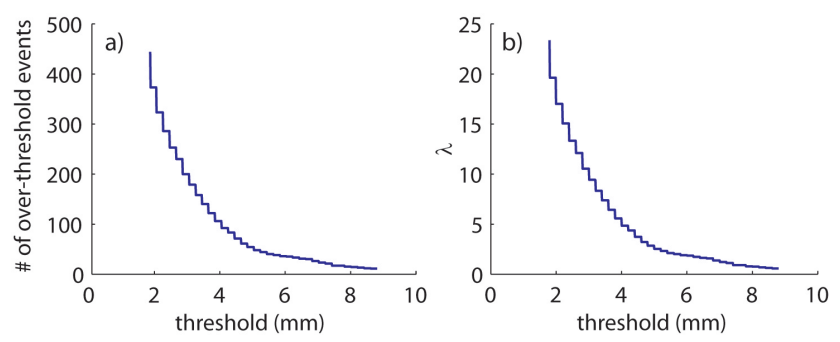

Fig. 7. (a) Total number of over-threshold events for different thresholds, and (b) average annual number of over-threshold events, $\lambda$, determined on the basis of rainfall data at the Faloria meteorological station during the period 1990-2008.

the considered threshold. Analogous analyses were carried out by considering two distinct periods, namely 1990-1998 and 1999-2008, to investigate possible variations in the frequency of over-threshold events, for instance related to climatic changes, as shown in Fig. 8. It clearly emerges that, for every considered threshold value, the number of average annual over-threshold events increased in the second decade (Fig. 8). In fact, the number of over-threshold events that characterises the period 1999-2008 is always greater than the number of over-threshold events in the period 1990-1998, showing that climatic changes could produce an increase in the number events potentially triggering debris flows. For example, for the critical threshold of $4.9 \mathrm{~mm} / 10 \mathrm{~min}$, the average annual number of over-threshold events increases from 2.8 in the period 1990-1998 to 3.9 in the period 1999-2008. We also performed the Wilcoxon rank sum test (Wilcoxon, 1945), which is equivalent to the Mann-Whitney U test (Mann and Whitney, 1947), a non-parametric test for assessing whether two independent samples of observations come from the same distribution. The null hypothesis is that the average annual number of over-threshold events obtained for the different thresholds in the period 1990-1998, $\lambda_{1}$, and the average annual number of over-threshold events in the period 1999-2008, $\lambda_{2}$, come from distributions with equal medians.

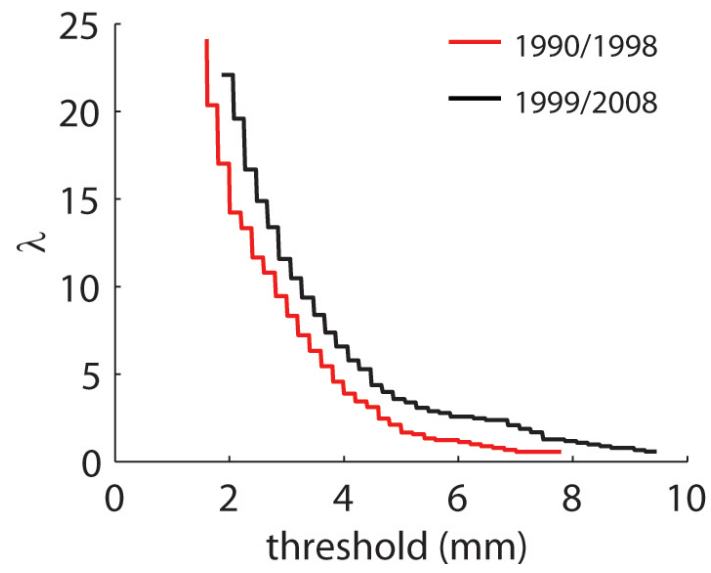

Fig. 8. Comparison of the average annual number of over-threshold events, $\lambda$, during the periods 1990-1998 and 1999-2008, determined on the basis of rainfall data at the Faloria meteorological station.

The test shows that the null hypothesis can be assumed to be true with a probability less than 0.1 , emphasising that the climatic changes observed at Faloria station produce overthreshold events characterised by different probability distributions.

\section{Discussion and concluding remarks}

The first results of this preliminary study on critical rainfall thresholds for debris-flow occurrence and climatic changes in the Dolomitic area of Cortina d'Ampezzo suggest a number of conclusions that can be summarized as follows.

The increase in the number of potentially triggering rainfall events, as well as their intensity, suggests climate changes in the study area. In the past century, the considered area has experienced changes in temperature, in the amount of total annual rainfall, and in the distribution of monthly rainfall. Maximum annual temperatures increased by up to $3^{\circ} \mathrm{C}$, and the distribution of rainfall experienced important changes during the autumn (October and November).

The differences displayed by the analysis of data measured at different stations show a large variability in rainfall distribution, particularly for intense, short-duration rainfalls all over the study area. This variability does not seem to be related exclusively to the elevation but also to local morphological conditions. As a consequence, in order to investigate the relationship between rainfall characteristics and debris-flow occurrence, it is important to consider rainfall data recorded at meteorological stations close to the sites where debris flows occurred. A larger monitoring network is needed to develop forecasting models and to further investigate the presence of a climatic change. 
As the mean frequency of rainfall events that can potentially trigger debris flows is 3.5 events per summer, it is necessary to use forecasting models that can account for this frequency and the possibility of major climate changes because models using only the annual maximum values, such as Gumbel or GEV, could underestimate the probability of occurrence, at least for small triggering thresholds.

Because of the marked variability displayed by the trends of intense rainfall events at local and global scales, more short-term rainfall data and further studies are needed to analyse the influence of global climate changes on the increase in intense rainfall events. In mountainous regions, rainfall data must be gathered from well-distributed rain gauge networks because of the influence of morphometric factors. At the global scale, and with the aid of remotesensing techniques, it will useful to analyse the correlations between regions with different climatic features, to understand the influence of global climate changes on precipitation patterns and mitigate the related social consequences.

Acknowledgements. This research was financially supported by the University of Padova, research projects CPDA085240 (Principal investigator: Mario Floris, Department of Geosciences) and GEORISKS (Principal investigator: Rinaldo Genevois, Department of Geosciences). The authors thank the reviewer Jeffrey Coe and an anonymous reviewer for their helpful suggestions to improve the paper.

Edited by: M. Arattano

Reviewed by: J. Coe and another anonymous referee

\section{References}

Berti, M., Genevois, R., Simoni, A., and Tecca, P. R.: Field observations of a debris flow event in the dolomites, Geomorphology, 29, 265-274, 1999.

Berti, M., Genevois, R., LaHusen, R., Simoni, A., and Tecca, P. R.: Debris flow monitoring in the Acquabona watershed (Dolomites, Italian Alps), Phys. Chem. Earth Pt. B., 25(9), 707-715, 2000.

Blijenberg, H. M.: Rolling Stones? Triggering and frequency of hill slope debris flows in the Bachelard Valley, Southern French Alps, Ph.D. thesis, Utrecht University, 233 pp., 1998.

Caine, N.: The rainfall intensity-during control of shallow landslides and debris flows, Geogr. Ann. A, 62, 23-27, 1980.

Cannon, S. H., Gartner, J. E., Rupert, M. G., Michael, J. A., Djokic, D., and Sreedhar, S.: Emergency Assessment of Debris-Flow Hazards from Basins Burned by the Grand Prix and Old Fires of 2003, Southern California, USGS, Open-File Report, 03-0475, 2003.

Chen, C. Y., Chen, T. C., Yu, F. C., Yu, W. H., and Tseng, C. C.: Rainfall duration and debris-flow initiated studies for real-time monitoring, Environ. Geol., 47, 715-724, 2005.

Chen, C. Y., Yu, F. C., Lin, S. C., and Cheung, K. W.: Discussion of landslide self-organized criticality and the initiation of debris flow, Earth Surf. Proc. Land., 32(2), 197-209, 2006.

Coe, J. A., Godt, J. W., Parise, M., and Moscariello, A.: Estimating debris-flow probability using fan stratigraphy, historic records, and drainage-basin morphology, Interstate 70 highway corridor, central Colorado, U.S.A., in: Debris-Flow Hazards Mitigation: Mechanics, Prediction, and Assessment, edited by: Rickenmann, D. and Cheng, Ch., Proceedings 3rd International DFHM Conference, Davos, Switzerland, 207-217, 2003.

Coe, J. A., Cannon, S. H., and Santi, P. M.: Introduction to the special issue on debris flows initiated by runoff, erosion, and sediment entrainment in western North America, Geomorphology, 96, 247-249, 2008a.

Coe, J. A., Kinner, D. A., and Godt, J. W.: Initiation conditions for debris flows generated by runoff at Chalk Cliffs, central Colorado, Geomorphology, 96, 270-297, 2008b.

Easterling, D. R., Evans, J. L., Groisman, P. Y., Karl, T. R., Kunkel, K. E., and Ambenje, P.: Observed variability and trends in extreme climate events: a brief review, B. Am. Meteorol. Soc., 81, 417-425, 2000.

Evans, S. G. and Clague, J. J.: Recent climatic change and catastrophic geomorphic processes in mountain environments, Geomorphology, 10, 107-128, 1994.

Eybergen, F. A. and Imeson, A. C.: Geomorphic processes and climatic change, Catena, 16, 307-319, 1989.

Fauchereau, N., Trzaska, S., Rouault, M., and Richard, Y.: Rainfall variability and changes in Southern Africa during the 20th century in the global warming context, Nat. Hazards, 29, 139-154, 2003.

Fowler, H. J. and Kilsby, C. G.: Implications of changes in seasonal and annual extreme rainfall, Geophys. Res. Lett., 30(13), 1720, doi:10.1029/2003GL017327, 2003

Fowler, H. J., Ekström, M., Kilsby, C. G., and Jones, P. D.: New estimates of future changes in extreme rainfall across the UK using regional climate model integrations. 1. Assessment of control climate, J. Hydrol., 300, 212-233, 2005.

Galgaro, A., Tecca, P. R., Genevois, R., and Deganutti, A. M.: Acoustic module of the Acquabona (Italy) debris flow monitoring system, Nat. Hazards Earth Syst. Sci., 5, 211-215, 2005, http://www.nat-hazards-earth-syst-sci.net/5/211/2005/.

Genevois, R., Tecca, P. R., Berti, M., and Simoni, A.: Pore pressure distribution in the initiation area of a granular debris flow, in: Proceedings of the 8th International Symposium on Landslides, edited by: Bromhead, E., Dixon, N., and Ibsen, M. L., Cardiff, 12, 615-620, 2000.

Genevois, R., Tecca, P. R., Deganutti, A. M., Galgaro, A., and Armento, C.: Scientific Contributions. European Project Torrent Hazard Control in the European Alps. Practical Tools and methodologies for Hazard Assessment and Risk Mitigation, Contract no. EVG1-CT1999-00012, Final Report, 67 pp., 2003.

Gong, D. Y. and Wang, S. W.: Severe summer rainfall in China associated with enhanced global warming, Clim. Res., 16, 5159,2000

Griffiths, P. G., Webb, R. H., and Melis, T. S.: Initiation of debris flows in tributaries of the Colorado River in Grand Canyon, Arizona. In: C.L. Chen, Editor, Debris-flow Hazards Mitigation, American Society of Civil Engineers, New York, 12-20, 1997.

Haeberli, W., Rickenmann, D., and Zimmerman, M.: Investigation of 1987 debris flows in the Swiss Alps: general concept and geophysical soundings, in: Hydrology in Mountainous regions. II Artificial reservoirs; Water and slopes, Proceedings of two Lausanne Symposia, IAHS, 194, 303-310, 1990. 
Jomelli, V., Brunstein, D., Grancher, D., and Pech, P.: Is the response of hill slope debris flows to recent climate change univocal? A case study in the Massif des Ecrins (French Alps), Climatic Change, 85, 119-137, 2007.

Keefer, D. K., Wilson, R. C., Mark, R. K., Brabb, E. E., Brown III, W. M., Ellen, S. D., Harp, E. L., Wieczorek, G. F., Alger, C. S., and Zatkin, R. S.: Real-time landslide warming during heavy rainfall, Science, 238, 921-925, 1987.

Mann, H. B. and Whitney, D. R.: On a test of whether one of two random variables is stochastically larger than the other, Ann. Math. Stat., 18, 50-60, 1947.

Monirul Qader Mirza, M.: Global warming and changes in the probability of occurrence of floods in Bangladesh and implications, Global Environ. Chang., 12, 127-138, 2002.

Pelfini, M. and Santilli, M.: Frequency of debris flows and their relation with precipitation: A case study in the Central Alps, Italy, Geomorphology, 101, 721-730, 2008.

Rickenmann, D. and Zimmermann, M.: The 1987 debris flow in Switzerland: documentation and analysis, Geomorphology, 8, 175-189, 1993.

Shieh, C. L. and Chen, L. Z.: Developing the critical line of debrisflow occurrence. Journal of Chinese Soil and Water Conservation, 26(3), 167-172, 1995 (in Chinese).

Shieh, C. L.: Debris flow surveillance in central Taiwan after Typhoon Toraji, Disaster Prevention Research Center, National Cheng-Kung University, 2002 (in Chinese).

Shieh, C. L., Chen, Y. S., Tsai, Y. J., and Wu, J. H.: Variability in rainfall threshold for debris flow after the Chi-Chi earthquake in central Taiwan, China, Int. J. Sediment Res., 24(2), 177-188, 2009.

Sillmann, J. and Roeckner, E.: Indices for extreme events in projections of anthropogenic climate change, Climatic Change, 86, 83-104, 2008.

Suwa, H. and Okuda, S.: Measurement of debris flows in Japan, in: Proc. IV Int. Conf and Field Workshop on Landslides, 391-400, 1985.

Takahashi, T.: Mechanical characteristics of debris flow, J. Hydr. Eng. Div.-ASCE, 104, 1153-69, 1978.

Takahashi, T.: Debris Flow, Disaster Prevention Research Institute, Kyoto University, Kyoto, Japan, 1981a.

Takahashi, T.: Estimation of potential debris flows and their hazardous zones, Natural Disaster Science, 3(1), 57-89, 1981b.
Takahashi, T.: Debris Flow, IAHR Monograph Series, Balkema, 1991.

Takahashi, T.: Initiation of flow of various types of debris flow, in: Proc. 2nd Int. Conf. on Debris flow hazards mitigation, edited by: Wieczorek, G. F. and Naeser, N. D., Balkema, Rotterdam, 15-25, 2000.

Tecca, P. R., Galgaro, A., Genevois, R., and Deganutti, A. M.: Development of a remotely controlled debris flow monitoring system in the Dolomites (Acquabona, Italy), Hydrol. Process., 17, 1771-1784, 2003.

Tecca, P. R and Genevois, R.: Field observations of the June 30 , 2001 debris flow at Acquabona (Dolomites, Italy), Landslides, 6(1), 39-45, doi:10.1007/s10346-009-0145-8, 2009.

Terlien, M. T. J.: The determination of statistical and deterministic hydrological landslide-triggering thresholds, Environ. Geol., 35(2-3), 124-130, 1998.

Tognacca, C. and Bezzola, G. R.: Debris flow initiation by channel bed failure, in: Debris flow hazard mitigation: mechanics, prediction and assessment, edited by: Chen, C.-I., ASCE, 45-53, 1997.

Tognacca, C., Bezzola, G. R., and Minor, H. E.: Threshold criterion for debris-flow initiation due to channel-bed failure. In: DebrisFlow Hazards Mitigation: Mechanics, Prediction and Assessment, edited by: Wieczorek, G. F. and Naeser, N. D., Balkema, 89-97, 2000.

Van Steijn, H.: Debris flow magnitude-frequency relationships for mountainous regions of central and Northwest Europe, Geomorphology, 15, 259-273, 1996.

Van Steijn, H.: Frequency of hillslope debris flows in the Bachelard valley (French Alps), in: Programme in Geomorphology, edited by: Panizza, M., Soldati, M., Bertacchini, M., Van Asch, W., and Malmusi, S., ICP-91/ 97-I-1226/07, 11, 15-24, 1999.

Wieczorek, G. F.: Effect of rainfall intensity and during on debris flows in central Santa Cruz Mountains, California, Flows/Avalanches: Process, Recognition and Mitigation, Geological Society of America, Reviews in Engineering Geology, 7, 93-104, 1987.

Wilcoxon, F.: Individual comparisons by ranking methods, Biometrics Bull., 1, 80-83, 1945.

Wilson, R. C. and Wieczorek, G. F.: Rainfall thresholds for the initiation of debris flows at La Honda, California, Environ. Eng. Geosci., 1(1), 11-27, 1995. 